UDC 378.147.39: 004

Olha V. Vashchylo

$\mathrm{PhD}$ of Pedagogical Sciences,

Senior Lecturer, Department of Theory, Practice and Translation of the English language

National Technical University of Ukraine "Igor Sikorsky Kyiv Polytechnic Institute", Kyiv, Ukraine

ORCID ID 0000-0001-7484-9435

olga_VV@ukr.net

\title{
EFFICIENCY OF DISTANCE LEARNING FOR FUTURE PHILOLOGISTS IN THE COVID-19 PANDEMIC
}

\begin{abstract}
The article is devoted to the questions of organizing English distant classes for future philologists and verifying the efficiency of the suggested approach. Distance learning was conducted at National Technical University of Ukraine "Igor Sikorsky Kyiv Polytechnic Institute" in the third and fourth semesters of the academic year 2020-2021. Second-year students (two groups) of the Faculty of Linguistics, specialty 035 "Philology", specialization 035.041 "Germanic languages and literature (including translation), primary - English" participated in the distance learning. The educational process in the distance mode encompassed distant classes, held through the video conferencing platform Zoom, and students' individual work, performed at the learning management system Canvas. The efficiency of teaching English distantly to future philologists was checked by conducting pre- and post-assessments with subsequent processing of the received data by methods of mathematical statistics. The efficiency of distance learning in general was verified using the statistical criterion $\varphi^{*}-$ Fisher z-transformation. The minimal sufficient achievement rate, used for Fisher z-transformation, was identified based on the fuzzy set theory by processing opinions of a group of experts. Lecturers at Igor Sikorsky Kyiv Polytechnic Institute, Department of the English language Theory, Practice and Translation were chosen as experts (ten respondents in total). The efficiency of distance learning in each group was verified using paired sample t-test. The results of the data processing by statistical methods proved the efficiency of the suggested approach to organizing distant English classes for future philologists that ensured combination of synchronous (using video conferencing platform Zoom) and asynchronous learning modes (using the learning management system Canvas). The results of the survey conducted among the participants of the educational process showed a positive attitude to the organization of the distance learning using the service Zoom and the system Canvas.
\end{abstract}

Keywords: efficiency of distance learning; Fisher z-transformation; paired sample t-test; video conferencing platform Zoom; learning management system Canvas.

\section{INTRODUCTION}

Problem statement. Under the threat of the coronavirus infection spread the Ministry of Education and Science of Ukraine [1] delegated the rights to organize the educational process using blended forms of learning and modern distance learning technologies to rectors of the universities, taking into account the specificity of the institution and incidence of COVID-19 in the participants of the educational process.

With the risk of coronavirus incidence being high, considering recommendations provided by the Ministry of Education and Science of Ukraine, the resolution of the Cabinet of Ministers dated July 22, 2020 no. 641 [2], as well as the Law of Ukraine "On Higher Education" [3], according to which higher educational institutions are given a certain level of autonomy, the Rector of National Technical University of Ukraine "Igor Sikorsky Kyiv Polytechnic Institute" adopted a resolution to organize the educational process distantly [4]. 
In connection with the above-mentioned, there appeared a necessity to organize the educational process for future philologists distantly, and verify the efficiency of the suggested approach subsequently.

Analysis of recent studies and publication. According to the resolution [4], the educational process in distant mode implied holding distant practical classes, online assessments and students' out-of-class individual work. Distant practical classes were to be held in videoconference mode with the use of modern distant learning tools.

During the pandemic a substantial amount of work is performed by students individually, out of class. In this context skills of organizing oneself and studying independently are of the utmost importance, especially for first-year and second-year students. Considering this fact, it is vital to introduce new forms of the individual out-of-class learning as well as methods to control students' learning activity. According to M. Odinokaya [5], to ensure that graduates demonstrate high professional competence that meets the needs of the modern society it is important to improve the organization of the individual out-of-class work.

Students' individual out-of-class work is based on the systematic, self-motivated, wellstructured activity that demands self-discipline, high level of self-awareness and consciousness. It is essential for students to demonstrate psychological readiness for individual work, develop knowledge on how to organize it and realize the stages it implies [6, p. 110].

One of the methods to enhance the efficiency of students' individual out-of-class work while learning foreign languages is to use innovative information and communication technologies (ICT). O. Malushko defines ICT as a set of digital technologies: methods, information and communication processes, software tools that are used to create, collect, process, store and share foreign language information to realize the educational purposes and serve the interests of the users [7, p. 176]. V. Berbets defines ICT in education as a set of brand-new educational and instructional materials, technical and instrumental tools, used to process, store, transmit and display information with regard for the specificity of the educational process $[8, \mathrm{p}$. 29].

ICT fosters students' autonomy and engagement. M. Daver characterizes autonomy as students' right to make their own decisions and realize them in the educational process while mastering a foreign language [9, p. 77] and distinguishes between active and reactive autonomy. Active autonomy implies students' readiness to be responsible for their own education, i.e., set personal educational goals, determine personal style of learning, select materials to study and analyze the results. Reactive autonomy, at the same time, holds a teacher responsible for rousing students' activity through motivating actions [9, p. 81-82].

Organizing students' individual work distantly the author of the article relies on the approach introduced by I. Zadorozhnya [10, p. 70], who specifies four levels of autonomy to master a foreign language competence (partial autonomy, with the lecturer exercising full control over students' actions; semi-autonomy, with the lecturer controlling students' actions indirectly; partially dependent autonomy, with its inherent flexible type of control; relatively full autonomy, with the lecturer exercising almost no control and students setting their intermediate and ultimate goals on their own) and considers it appropriate to use partially dependent autonomy with a relatively flexible type of control, i.e., students' individual work is controlled indirectly by the lecturer through the use of ICT, namely educational Internet platforms.

Distant practical classes that are conducted live and in real time (synchronous learning) are supported by individual out-of-class asynchronous learning with the use of remote teaching 
platforms or learning management systems, which allows educators to reach almost the same degree of efficiency as in an in-person classroom [11].

It is vital to look into the questions of the distant English classes organization for future philologists, which implies using Zoom for practical classes and Canvas for individual out-ofclass work with its subsequent efficiency verification. The aforementioned determines the significance of the given article.

The purpose of the article is to evaluate the effectiveness of the distant English classes organization for future philologists in the times of pandemic that involves holding practical classes through the video-conferencing service Zoom and performing students' individual out-ofclass work at the learning management system Canvas.

\section{METHODS OF THE RESEARCH}

Regarding the methods applied in the course of the study the following ones are to be enumerated: pedagogical observation, quantitative and qualitative analysis, interpretation (reasoning and comparison), control and measuring (pre- and post-assessments), data processing by means of statistical methods. To verify the efficiency of distance learning in general, the statistical criterion $\varphi^{*}$ - Fisher z-transformation, based on the minimal sufficient achievement rate calculation, was used. To identify the minimal sufficient achievement rate, the fuzzy set theory was applied. To check the efficiency of distance learning in each group, a paired sample ttest was applied. It has to be added that a survey was conducted using Google Forms to identify the students' attitude to the distance learning organization.

\section{ORGANIZATION AND RESULTS OF THE RESEARCH}

Distance learning took place at National Technical University of Ukraine "Igor Sikorsky Kyiv Polytechnic Institute" in the third and fourth semesters, academic year 2020-2021. The second-year students (two groups) of the faculty of Linguistics majoring in Philology (Germanic Languages and Literatures (including translation), primary - English) participated in the distance learning.

Distant educational process encompassed distant practical classes, held through the video conferencing platform Zoom, and students' individual work, performed at the learning management system Canvas.

The education with the use of the video conferencing platform Zoom was organized as follows. Students installed Zoom either at their computer desktops, mobile phones or other appliances. On receiving the invitation letters (containing the link, the conference ID and the access code) to their e-mails, students joined the video-conference in due time according to the schedule. Distant classes through Zoom were held according to the curriculum, using Upstream Upper-Intermediate in the third semester (modules Live and Learn, That's Life), and Upstream Advanced in the fourth semester (modules On Top of the World, Society).

The classes aimed at the effective formation of the students' communicative competence which was ensured by performing the tasks on:

- comprehending oral speech (both familiar and unfamiliar topics);

- producing clear, articulate, coherent speech on a wide range of topics, providing arguments, reasons and relevant examples; 
- producing fluent speech without long-lasting pauses;

- comprehending articles, reports, and presentations that cover relevant aspects of modern living, using reference material;

- writing detailed, coherent and cohesive texts, expressing one's opinion and presenting arguments and facts;

- translating written and oral texts of familiar genres, retaining their stylistic and pragmatic parameters [12].

The main advantages of using the video conferencing platform Zoom in the educational process are: availability to every Internet user; possibility for a large number of users to be involved at the same time; high-quality video and audio; affordability (a conference lasts for 40 minutes, then an update is required); easy and intuitive interface; general chat room to exchange texts, charts, audio, video, etc.; virtual chat rooms to organize students' pair/group work (a lecturer appoints participants of every group, sets the time limit); shared usage of the screen; using Zoom together with Google Disk, Dropbox, etc.

The distant classes on the video conferencing platform Zoom were devoted to oral frontal discussions on the topics of the curriculum; students prepared and presented dialogues in pairs; reported on the results of group discussions held in chat rooms; performed tasks on audio/video comprehension that implied semantic, lexical, and grammatical analysis with further discussion of the content; trained the usage of new lexical units through interactive learning; presented the results of their own research, discussed with the lecturer the tasks they performed and uploaded to Canvas during their individual work.

Students' out-of-class individual work was organized with the help of the learning management system Canvas. This particular system was chosen due to the author's positive experience in organizing students' out-of-class individual work within the methodology of teaching English monologue production to future mechanical engineers [13].

The learning management system Canvas belongs to Massive open online courses (MOOC) that are characterized by massive interactive participation with the use of e-learning technologies and open Internet access. These courses demonstrate a wide range of features to ensure high quality of the educational process [14].

The educational content which is published at Canvas is organized into units and modules, the submission deadline is set, the number of attempts, type of the task and details of the assessment (points, percentage, passed/failed) as well as format of the submitted task (online, textfile/audio/video upload, website link, commentary) are indicated. The system also accumulates all the tasks performed by a student (i.e., a student's portfolio) that are readily available to the lecturer and students. Another advantage of Canvas is its flexibility. Being compatible with a number of mobile devices and operating systems (iPad, iPhone, Android, etc.), the learning management system in question can be used from any place at any time. Besides, a lecturer saves time of a video-conference as homework assignments together with additional materials and instructions are published at Canvas and are available to students 24/7. The system assists in students' choosing their individual learning trajectory as it enables them to perform tasks at their own pace.

Working individually at Canvas students performed various tasks: summarized the comprehended information, recorded and uploaded their own video as a result; translated texts and sentences to improve lexical and grammatical skills in a written form; performed and uploaded tasks connected with the development of academic writing skills; comprehended podcasts, created and uploaded their own audio and video recordings expressing their opinion on the issue in question, etc. 
Efficiency of the distance learning verification. To check the efficiency of the approach that implies organizing distance learning for future philologists in the synchronous (using video conferencing platform Zoom) and asynchronous (using learning management system Canvas) modes of learning, pre- and post-assessments as well as data analysis by methods of mathematical statistics were carried out.

The assessments aimed to identify the level of the students' language competence formation and were based on the International language tests, such as B2 First (FCE), Test of English as a Foreign Language (TOEFL), International English Language Testing System (IELTS), EF SET English Certificate and others.

Table 1 shows the results of the pre- and post-assessments as well as students' achievement rate in the first group (GR-1). The achievement rate was calculated by the formula: $R_{a c h}=N / P$, where $\mathrm{N}$ is the number of points scored by a student, and $\mathrm{P}$ is a maximum number of points.

\section{Assessment results in GR-1}

\begin{tabular}{|l|c|c|c|c|c|}
\hline \multicolumn{1}{|c|}{ GR-1 } & $\begin{array}{c}\text { Score in the pre- } \\
\text { assessment }\end{array}$ & $\begin{array}{c}\text { Score in the } \\
\text { post- } \\
\text { assessment }\end{array}$ & $\begin{array}{c}\text { Achievement rate } \\
\text { by the results of } \\
\text { the pre-assessment }\end{array}$ & $\begin{array}{c}\text { Achievement rate } \\
\text { by the results of } \\
\text { the post- } \\
\text { assessment }\end{array}$ & $\begin{array}{c}\text { Achievement rate } \\
\text { increase }\end{array}$ \\
\hline 1. Abr-ch & 80 & 97 & 0,80 & 0,97 & 0,17 \\
\hline 2. Anis-va & 66 & 80 & 0,66 & 0,80 & 0,14 \\
\hline 3. Ber-ka & 68 & 85 & 0,68 & 0,85 & 0,17 \\
\hline 4. Hay-ko & 67 & 88 & 0,67 & 0,88 & 0,21 \\
\hline 5. H-ts & 68 & 86 & 0,68 & 0,86 & 0,18 \\
\hline 6. If-ka & 60 & 65 & 0,60 & 0,65 & 0,05 \\
\hline 7. Maks-k & 83 & 97 & 0,83 & 0,97 & 0,14 \\
\hline 8. Mash-k & 74 & 77 & 0,74 & 0,77 & 0,03 \\
\hline 9. Par-ts & 81 & 97 & 0,81 & 0,97 & 0,16 \\
\hline 10. Pys-na & 68 & 74 & 0,68 & 0,74 & 0,06 \\
\hline 11. S-va & 75 & 86 & 0,75 & 0,86 & 0,11 \\
\hline 12. Ch-no & 82 & 96 & 0,82 & 0,96 & 0,14 \\
\hline 13. Sh-ko & $\mathbf{7 8}$ & 93 & 0,78 & 0,93 & 0,15 \\
\hline Mean score in & $\mathbf{7 3 , 0 8}$ & $\mathbf{8 6 , 2 3}$ & $\mathbf{0 , 7 3}$ & $\mathbf{0 , 8 6}$ & $\mathbf{0 , 1 3}$ \\
\hline GR-1 & $\mathbf{1 0 0}$ & $\mathbf{1 0 0}$ & $\mathbf{1}$ & $\mathbf{1}$ & - \\
\hline Maximum score & & & & & \\
\hline
\end{tabular}

Table 2 provides results of the pre- and post-assessments together with every student's achievement rate in the second group (GR-2).

Table 2

Assessment results in GR-2

\begin{tabular}{|l|c|c|c|c|c|}
\hline \multicolumn{1}{|c|}{ GR-2 } & $\begin{array}{c}\text { Score in the pre- } \\
\text { assessment }\end{array}$ & $\begin{array}{c}\text { Score in the } \\
\text { post- } \\
\text { assessment }\end{array}$ & $\begin{array}{c}\text { Achievement rate } \\
\text { by the results of } \\
\text { the pre-assessment }\end{array}$ & $\begin{array}{c}\text { Achievement rate } \\
\text { by thesults of } \\
\text { the post- } \\
\text { assessment }\end{array}$ & $\begin{array}{c}\text { Achievement rate } \\
\text { increase }\end{array}$ \\
\hline 1. Ant-uk & 79 & 97 & 0,79 & 0,97 & 0,18 \\
\hline 2. Bel-y & 67 & 73 & 0,67 & 0,73 & 0,06 \\
\hline 3. Bur-va & 78 & 95 & 0,78 & 0,95 & 0,17 \\
\hline 4. Ver-d & 78 & 95 & 0,78 & 0,95 & 0,17 \\
\hline 5. Vys-y & 72 & 80 & 0,72 & 0,80 & 0,08 \\
\hline 6. Vl-kh & 77 & 92 & 0,77 & 0,92 & 0,15 \\
\hline
\end{tabular}




\begin{tabular}{|l|c|c|c|c|c|}
\hline 7. Zhar-va & 70 & 76 & 0,70 & 0,76 & 0,06 \\
\hline 8. Z-va & 68 & 85 & 0,68 & 0,85 & 0,17 \\
\hline 9. Kol-n & 65 & 71 & 0,65 & 0,71 & 0,06 \\
\hline 10. Koh-n & 68 & 78 & 0,68 & 0,78 & 0,10 \\
\hline 11. Mykh-yn & 60 & 69 & 0,60 & 0,69 & 0,09 \\
\hline 12. Puh-va & 77 & 85 & 0,77 & 0,85 & 0,08 \\
\hline 13. Hal-ov & 78 & 93 & 0,78 & 0,93 & 0,15 \\
\hline Mean score in GR-2 & $\mathbf{7 2 , 0 8}$ & $\mathbf{8 3 , 7 7}$ & $\mathbf{0 , 7 2}$ & $\mathbf{0 , 8 4}$ & $\mathbf{0 , 1 2}$ \\
\hline Maximum score & 100 & 100 & 1 & 1 & - \\
\hline
\end{tabular}

Data processing by methods of mathematical statistics makes it possible to ascertain the efficiency of the distance learning in general, along with the efficiency of the suggested learning in each group (GR-1, GR-2).

The statistical criterion $\varphi^{*}$ - Fisher z-transformation [15, p. 158], used to compare two samples by a certain effect's frequency, was applied to check the efficiency of the distance learning in general. The effect implies students' achievement of the minimal sufficient achievement rate. To identify the minimal sufficient achievement rate, the mathematical apparatus of fuzzy sets was used [16], [17], [18].

Let $\mathrm{E}$ be a universal set, $\mathrm{x}-\mathrm{a}$ generic element of $\mathrm{E}$, and $\mathrm{R}-\mathrm{a}$ certain property. The fuzzy subset $\mathrm{A}$ of the universal set $\mathrm{E}$, elements of which meet the property $\mathrm{R}$, is defined as a set of ordered pairs $A=\left\{\mu_{A}(x) / x\right\}$, where $\mu_{A}(x)$ is the membership function that can take any value within the interval $[0,1]$.

The membership function $\mu_{\mathrm{A}}(\mathrm{x})$ assigns a grade of membership of an element $\mathrm{x}$ to a fuzzy subset A. To describe the task of decision-making, linguistic variables introduced by L. Zadeh [19] are used. A set of values of a linguistic variable comprises a term-set of this variable. An element of a term-set is called a term. To identify the linguistic variable, it is essential to set its name, term-set and a scope of this variable (D).

Let the linguistic variable "achievement rate" be characterized by the terms "sufficient" and "insufficient", its scope lies within the interval from 0 to 1 . The corresponding term-set is called a set of basic values or a basic set.

Then the fuzzy variable will be defined by the following elements:

<achievement rate, $[0,1], \mu_{1}(x) / x, \mu_{2}(x) / x>$,

where: $[0,1]$ - a set of basic values (a basic set);

$\mu_{1}(x) / x-$ a fuzzy set, corresponding to the term "insufficient";

$\mu_{2}(x) / x$ - a fuzzy set, corresponding to the term "sufficient".

Practical use of the fuzzy sets theory implies generating membership functions that are considered to be main characteristics of linguistic terms.

Membership functions of fuzzy sets that characterize terms "sufficient", "insufficient" (used to evaluate the linguistic variable "achievement rate") are to be generated.

Generation of membership functions is based on the statistical processing of expert estimation [17]. Every expert completes a questionnaire expressing their opinion on whether the element of the basic set $D$ has properties of the fuzzy set $\left(\mu_{1}(x) / x, \mu_{2}(x) / x\right)$. Expert estimates are binary, i.e., acquire values 0 or 1 , where 1 (0) indicates whether the element $x$ of the basic set $D$ shows (does not show) properties of one of the sets $\left(\mu_{1}(x) / x, \mu_{2}(x) / x\right)$.

Lecturers at National Technical University of Ukraine "Igor Sikorsky Kyiv Polytechnic Institute", Department of the English language Theory, Practice and Translation were chosen as experts (a group of ten respondents). The results of the survey are given in the Table 3. 


\section{Expert estimation results}

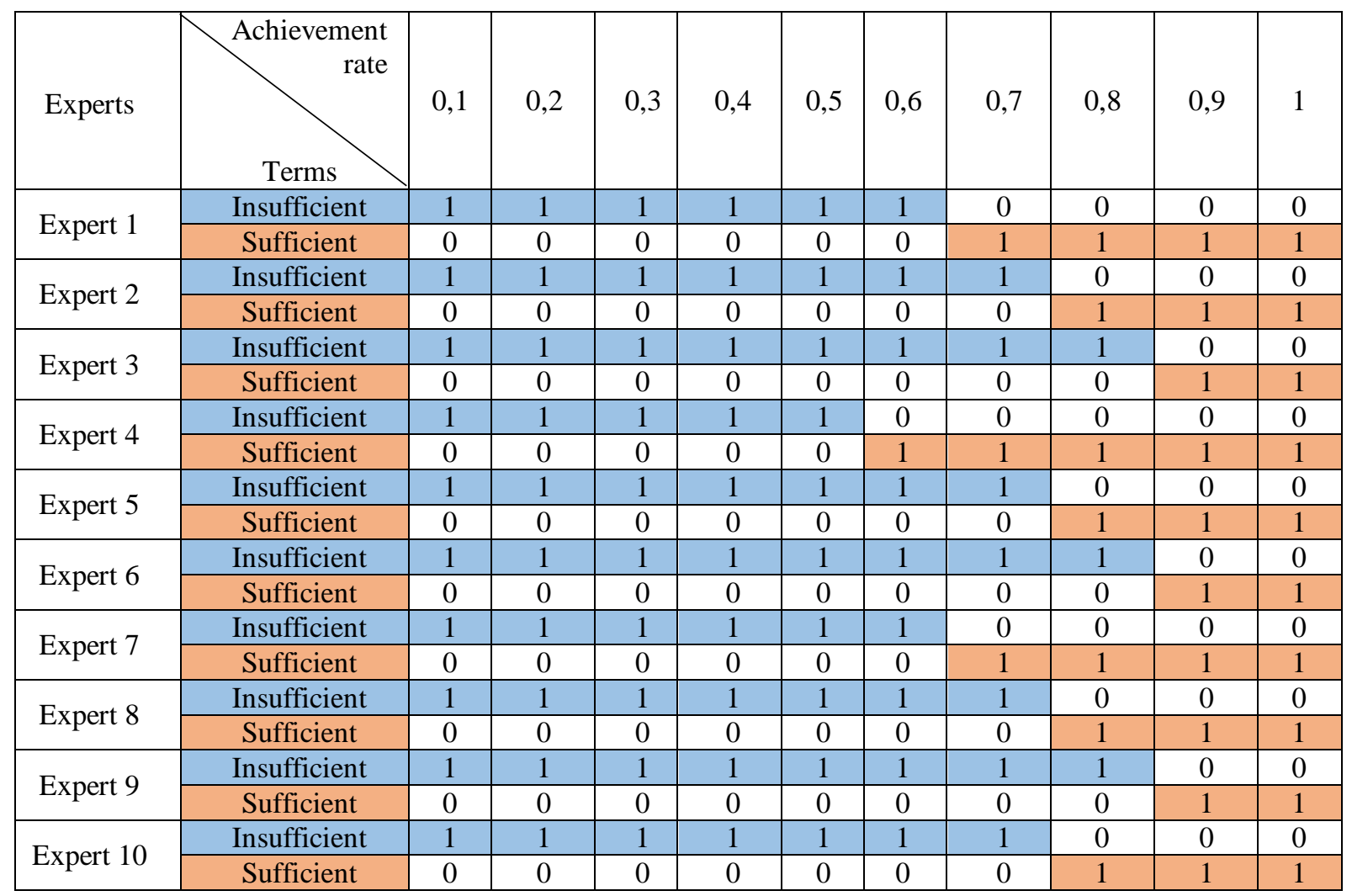

Results of the expert estimation processing are given in the Table 4.

Results of the expert estimation processing

\begin{tabular}{|c|c|c|c|c|c|c|c|c|c|c|}
\hline $\begin{array}{c}\text { Achievement } \\
\text { rate }\end{array}$ & 0,1 & 0,2 & 0,3 & 0,4 & 0,5 & 0,6 & 0,7 & 0,8 & 0,9 & 1 \\
\hline Terms & & & & & & & & & & \\
\hline \multirow{2}{*}{ Insufficient } & 10 & 10 & 10 & 10 & 10 & 9 & 7 & 3 & 0 & 0 \\
\hline & 1 & 1 & 1 & 1 & 1 & 0,9 & 0,7 & 0,3 & 0 & 0 \\
\hline \multirow{2}{*}{ Sufficient } & 0 & 0 & 0 & 0 & 0 & 1 & 3 & 7 & 10 & 10 \\
\hline & 0 & 0 & 0 & 0 & 0 & 0,1 & 0,3 & 0,7 & 1 & 1 \\
\hline
\end{tabular}

In Table 4 the numbers above the line show the expert votes stating that the element $x$ of the basic set $D$ belongs to the fuzzy set $\left(\mu_{1}(x) / x, \mu_{2}(x) / x\right)$. The numbers below the line show the grade of membership that is calculated by dividing the number of the votes in favor of the element $x$ belonging to the fuzzy set by the number of experts. The membership functions curves are illustrated in Figure 1. 


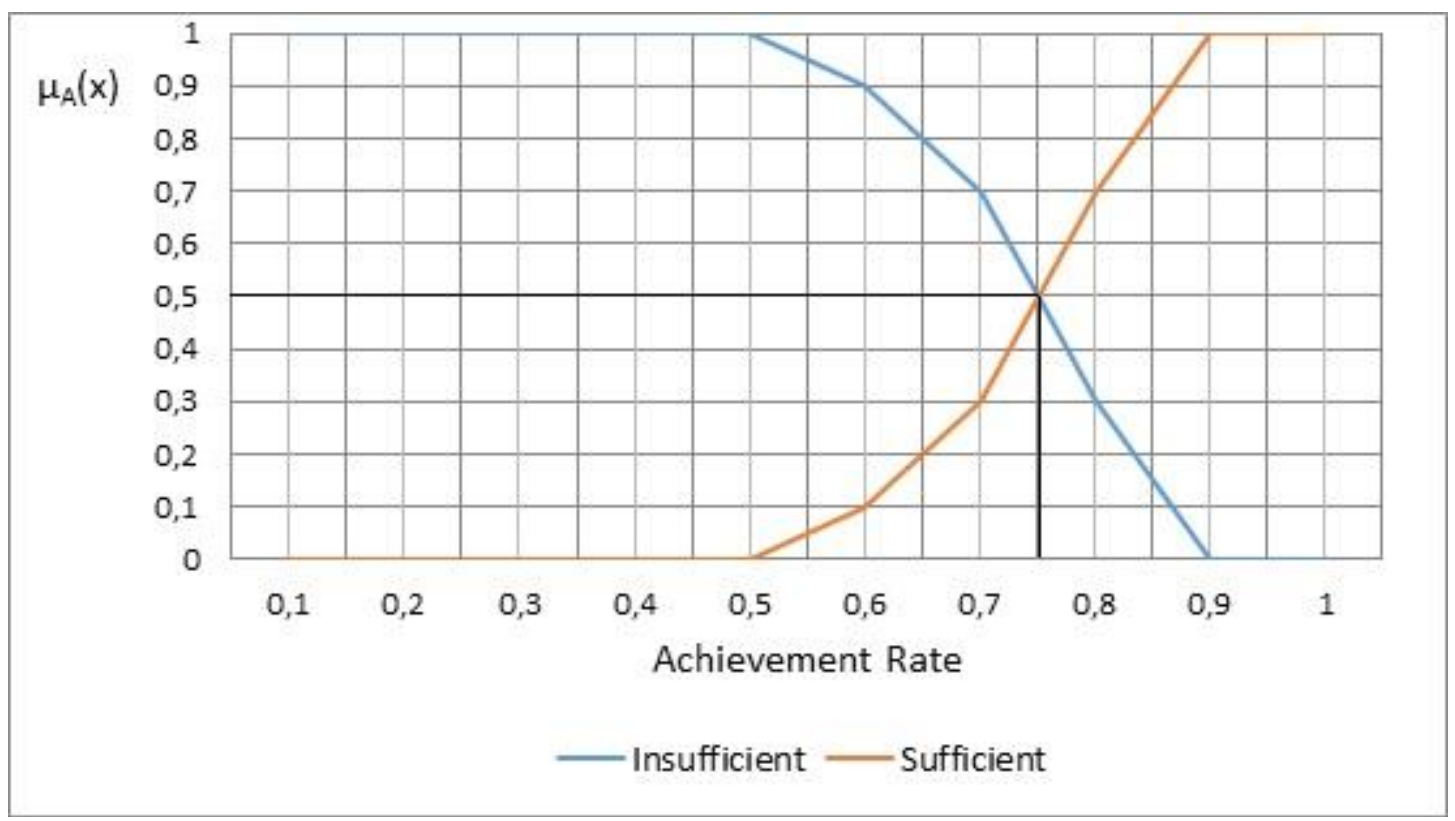

Fig.1. Membership functions curves

The numerical value of the achievement rate by which the membership functions of the terms "sufficient" and "insufficient" take the same values is chosen to be the minimal sufficient achievement rate. As can be seen from Fig. 1, 0,75, $\left(\mu_{1}(0,75)=\mu_{2}(0,75)=0,5\right)$ is accepted for such a value.

Thus, checking the efficiency of the distance learning in general using the statistical criterion $\varphi^{*}$ - Fisher z-transformation, 0,75 is taken as the minimal sufficient achievement rate.

Having defined the minimal sufficient achievement rate, it is necessary to build a table that shows the percentage of students demonstrating sufficient/insufficient achievement rate (Table 5).

Table 5

Pre- and post-assessment results correlation in distance learning by the achievement rate $\geq 0,75$

\begin{tabular}{|c|c|c|c|c|c|}
\hline & \multicolumn{2}{|c|}{ Achievement rate $\geq 0,75$} & \multicolumn{2}{c|}{ Achievement rate $<0,75$} & \multirow{2}{*}{$\begin{array}{c}\text { Total number } \\
\text { of students }\end{array}$} \\
\cline { 2 - 5 } & $\begin{array}{c}\text { Number of } \\
\text { students }\end{array}$ & $\%$ & $\begin{array}{c}\text { Number of } \\
\text { students }\end{array}$ & $\%, 23 \%$ & 26 \\
\hline $\begin{array}{c}\text { After the } \\
\text { distance } \\
\text { learning }\end{array}$ & 21 & $80,77 \%$ & 5 & $53,85 \%$ & 26 \\
\hline $\begin{array}{c}\text { Before the } \\
\text { distance } \\
\text { learning }\end{array}$ & 12 & $46,15 \%$ & 14 & & 52 \\
\hline Total & 33 & & 19 & & 26 \\
\hline
\end{tabular}

Two hypotheses are to be formulated. 
$\mathrm{H}_{0}$ : The number of students demonstrating the rate $\geq 0,75$ in the post-assessment during the distance learning does not exceed the number of students demonstrating the rate in the preassessment during the distance learning.

$\mathrm{H}_{1}$ : The number of students demonstrating the rate $\geq 0,75$ in the post-assessment during the distance learning exceeds the number of students demonstrating the rate in the pre-assessment during the distance learning.

The values of $\varphi_{1}$ and $\varphi_{2}$ that correlate with the percentage from every sample are defined by the table $[15$, p. 330].

$\varphi_{1}(80,77 \%)=2,234 ; \varphi_{2}(46,15 \%)=1,493$.

The reference value $-\varphi^{*}$ empirical is to be calculated:

$$
\varphi_{\text {емп }}^{*}=\left(\varphi_{1}-\varphi_{2}\right) \cdot \sqrt{\frac{n_{1} \times n_{2}}{n_{1}+n_{2}}}=(2,234-1,493) \cdot \sqrt{\frac{26 \times 26}{26+26}}=2,67
$$

The following values are taken as critical $\left(\varphi^{*}\right.$ cr) $[15, \mathrm{p} 162]$ :

$\varphi^{*}{ }_{\mathrm{\kappa p}}=\left\{\begin{array}{l}1,64(p \leq 0,05) \\ 2,31(p \leq 0,01)\end{array}\right.$

If $\varphi^{*}{ }_{\mathrm{emp}}<\varphi^{*}{ }_{\mathrm{cr}}$, the hypothesis $\mathrm{H}_{0}$ is taken, alternatively the hypothesis $\mathrm{H}_{1}$ is to be taken. The results are shown on the value axis (Figure 2).

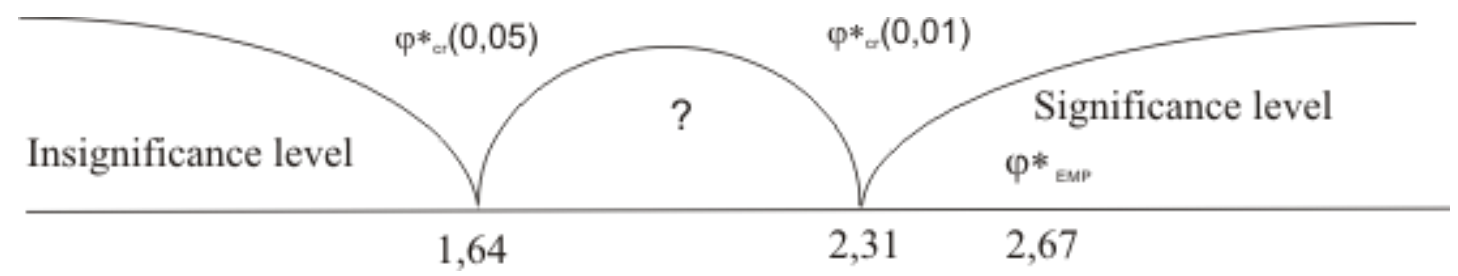

Fig. 2. Value axis demonstrating the results

As Figure 2 shows, the received value $\varphi^{*}$ emp $(2,67)$ exceeds $\varphi^{*}$ cr and falls to the zone of statistical significance. Therefore, the hypothesis $\mathrm{H}_{0}$ is discarded and the hypothesis $\mathrm{H}_{1}$ is taken.

The received data proves the suggested approach on the distance learning organization to be effective.

To check the efficiency of the suggested approach on the distance learning organization in each group (G-1; G-2), paired sample t-test (i.e., the students' results before and after the distance learning in each group) was applied. The precondition for the t-test application in this case is the significant correlation between the paired samples [20, p. 50]. Thus, to check the possibility of the t-test application, the empirical correlation coefficient is to be calculated by the formula [21, p. 464]:

$$
r=\frac{\sum_{i=1}^{n}\left(x_{i}-\bar{x}\right) \times\left(y_{i}-\bar{y}\right)}{\sqrt{\sum_{i=1}^{n}\left(x_{i}-\bar{x}\right)^{2} \times \sum_{i=1}^{n}\left(y_{i}-\bar{y}\right)^{2}}} ;
$$

where $x_{i}$ - grade received by the $\mathrm{i}$-th student in a group in the assessment before the distance learning;

$\bar{x}$ - arithmetic mean value; learning;

$y_{i}-$ grade received by the $\mathrm{i}$-th student in a group in the assessment after the distance

$\bar{y}$ - arithmetic mean value;

$n$ - number of students in a group. 
Correlation is considered to be substantial if the correlation coefficient $r$, calculated by the formula (2), is $r \geq 0,7$ [20, p. 39], [21, p. 464].

Assessment of the efficiency of the distance learning in GR-1 is to be regarded. The correlation coefficient was calculated using specially designed Windows Form-Application. As it equals $\mathrm{r}_{\mathrm{GR}-1}=0,85$, the substantial correlation is to be noted. Under these conditions, it is possible to conduct the statistical analysis using paired sample t-test.

Two statistical hypotheses are to be formulated:

$\mathrm{H}_{0}$ : The average results received after the distance learning do not differ significantly from the average results gained before the distance learning with regard to the group in question;

$\mathrm{H}_{1}$ : The average results received after the distance learning differ significantly from the average results gained before the distance learning with regard to the group in question.

As the samples in question are paired samples, in fact pairs of values, the subject of analysis is the difference between these pairs of values. The control value $t$ is calculated by the formula [20, p. 49]:

$$
t=\sqrt{n} \times \frac{\left|\bar{x}_{d}\right|}{\sqrt{s_{d}{ }^{2}}},
$$

where $\bar{x}_{d}=\frac{\sum_{i=1}^{n}\left(y_{i}-x_{i}\right)}{n}-$ mean value of the difference of the pairs of students' grades before and after the distance learning;

$S_{d}{ }^{2}$ - variance of the difference of the pairs of values;

$n=13$ - number of students in GR-1.

Variance $S_{d}{ }^{2}$ is calculated by the formula:

$$
S_{d}{ }^{2}=\frac{1}{n-1} \times \sum_{i=1}^{n}\left(x_{d_{i}}-\bar{x}_{d}\right)^{2},
$$

where $x_{d_{i}}=y_{i}-x_{i}$ - difference between the grades of the $\mathrm{i}$-th student in the pre- and postassessments during the distance learning.

By the table of the critical values for the t-test [21, p. 76-77] for the significance level $p$ and the degree of variance $\mathrm{k}=\mathrm{n}-1, \mathrm{t}_{\mathrm{cr}}$ is found.

If $t_{c r}>t$, the hypothesis $H_{0}$ is taken; if $t_{c r}<t$, the hypothesis $H_{0}$ is discarded and the hypothesis $\mathrm{H}_{1}$ is taken.

For $\mathrm{k}=13-1=12, \mathrm{t}_{\mathrm{cr}}=\left\{\begin{array}{l}2,18(p=0,05) ; \\ 3,06(p=0,01) .\end{array}\right.$

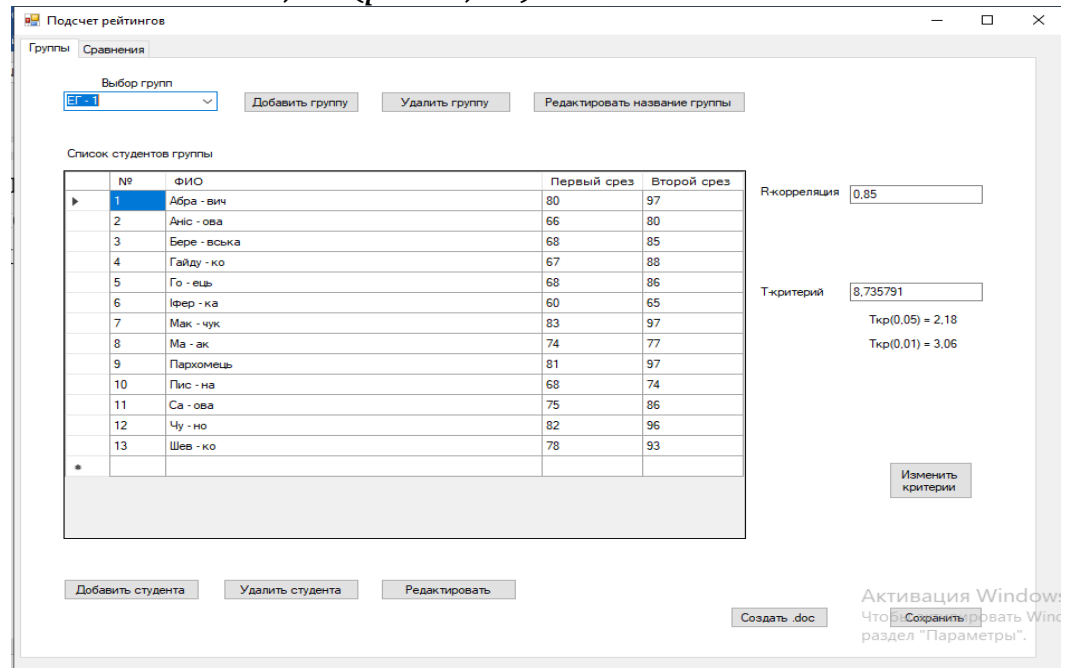

Fig. 3. Results of the calculations for GR-1 using Windows Form-Application 
The control value $t$ was calculated by the formula (3) using Windows Form-Application, resulting into $\mathrm{t}=8,74$.

The calculations of the correlation coefficient and the control value $t$ using Windows FormApplication for GR-1 is demonstrated in Figure 3. learning.

As $t$ exceeds $t_{c r}$, the hypothesis $H_{1}$ is taken, which proves the efficiency of the distance

Calculations in GR-2 were done similarly. The results are shown in the Table 6.

Table 6

Efficiency of the distance learning in GR-1, GR-2

\begin{tabular}{|c|c|c|c|c|c|}
\hline GR & $\begin{array}{c}\text { Empirical } \\
\text { correlation } \\
\text { coefficient }(\mathrm{r})\end{array}$ & $\begin{array}{c}\text { Control value } \\
(\mathrm{t})\end{array}$ & $\begin{array}{c}\text { Critical value } \\
\text { for the t-test } \\
\left(\mathrm{t}_{\mathrm{cr}}\right)\end{array}$ & $\begin{array}{c}\text { Critical } \\
\text { value for the } \\
\mathrm{t} \text {-test }\left(\mathrm{t}_{\mathrm{cr}}\right)\end{array}$ & $\begin{array}{c}\text { Accepted } \\
\text { hypothesis } \\
\mathrm{p}=0,05\end{array}$ \\
\hline GR-1 & 0,85 & 8,74 & 2,18 & 3,06 & $\mathrm{H}_{1}$ \\
\hline GR-2 & 0,95 & 9,94 & 2,18 & 3,06 & $\mathrm{H}_{1}$ \\
\hline
\end{tabular}

The analysis of the data in the table shows that the control value $t$ exceeds $t_{c r}$ in both groups, which proves the efficiency of the suggested approach to the distance learning organization.

Processing of the data received during the distance learning by statistical methods proved the efficiency of the suggested approach to the distance learning organization in general as well as its efficiency in each group.

To establish the students' attitude toward the distance learning organization, a survey was conducted using Google Forms. The survey encompassed two major aspects: the students' attitude to the distant education on the whole and their attitude to the distance learning through video conferencing platform Zoom and the learning management system Canvas.

Answering the question "What is your attitude towards the distance learning?", 77\% respondents considered distance learning to be acceptable during the pandemic, part of the respondents $(17 \%)$ expressed positive attitude towards the distance learning, indicating it to be even better than the in-class learning. At the same time, 6\% of the respondents expressed negative attitude to the distance learning.

The following benefits of the distance learning were mentioned by the respondents: lack of necessity to spend time and money on commuting (78\%); more time to sleep (58\%); more free time (44\%).

Among the negative aspects the following were mentioned: necessity to work at the computer for an extended period of time $(82 \%)$; more workload with an emphasis being made on the individual out-of-class work (60\%); lack of personal interaction with the groupmates and lecturers (47\%).

Responding to the question "Did you enjoy working through the video conferencing platform Zoom?", the majority of the students (83\%) expressed their satisfaction. To the question "How did you like the individual out-of-class work at the learning management system Canvas?" most of the respondents (57\%) answered they were absolutely satisfied, while 39\% - quite satisfied. 
Among the benefits of Canvas implementation in the educational process, the majority of the respondents mentioned: user-friendliness (74\%); 24h accessibility (35\%); possibility to record, edit and upload students' own audio- and videofiles (26\%).

Answering the question "Are you pleased with the distance learning organization which implies integrated usage of the platform Zoom and system Canvas?", most of the respondents (58\%) expressed their satisfaction, with $38 \%$ of the respondents expressing their strong satisfaction at the same time.

\section{CONCLUSIONS AND PROSPECTS FOR FURTHER RESEARCH}

Thus, questions of organizing English distance learning for future philologists and verifying the efficiency of the suggested approach have been highlighted in the article. Distant classes were held at the video conferencing platform Zoom. Students' out-of-class individual work was performed at the learning management system Canvas, which was chosen due to the author's positive experience in organizing individual out-of-class work while teaching English to future mechanical engineers.

To check the efficiency of the suggested approach to organizing distant English classes for future philologists, pre- and post-assessments as well as data analysis by methods of mathematical statistics were carried out. The statistical criterion $\varphi^{*}-$ Fisher $\mathrm{z}$-transformation, based on the minimal sufficient achievement rate calculation, was used to check the efficiency of distance learning in general. To identify the minimal sufficient achievement rate $(0,75)$, the fuzzy set theory was applied. To check the efficiency of distance learning in each group (GR-1; GR-2), a paired sample t-test was applied. As the significant correlation between the paired samples was the precondition for the application of the t-test, the empirical correlation coefficient was calculated using a specially designed Windows Form-application.

The results of the data processing by means of statistics showed the efficiency of the suggested approach to organizing distant learning for future philologists that ensured combination of synchronous (using video conferencing platform Zoom) and asynchronous learning modes (using the learning management system Canvas).

The results of the survey conducted among the participants of the educational process revealed their positive attitude toward distance learning in general as well as the distance learning organization through Zoom and Canvas.

The prospects for further research are predetermined by the necessity to use the gained experience in organizing distance learning under standard conditions when the pandemic finishes.

\section{REFERENCES (TRANSLATEDANDTRANSLITERATED)}

[1] Letter of the Ministry of Education and Science of Ukraine № 1/9-178 dated March 27, 2020 "On the completion of the 2019/2020 academic year". [Online]. Available: https://mon.gov.ua/ua/npa/shodozavershennya-201920-navchalnogo-roku. (in Ukrainian)

[2] Resolution of the Cabinet of Ministers dated July 22, 2020 no. 641 "About establishment of quarantine and introduction of the strengthened anti-epidemic actions in the territory with considerable spread of sharp respiratory disease of COVID-19, of SARS-CoV-2 caused by coronavirus". [Online]. Available: https://www.kmu.gov.ua/npas/pro-vstanovlennya-karantinu-ta-zapr-641. (in Ukrainian)

[3] Verkhovna Rada of Ukraine. Law of Ukraine "On Higher Education” dated July 01, 2014 № 1556-VII. [Online]. Available: https://zakon.rada.gov.ua/laws/show/1556-18\#Text. (in Ukrainian) 
[4] Resolution of Rector of KPI dated August 21, 2020 no. 7-148 "About the organization of the educational process in the first term of 2020-2021”. [Online]. Available: https://document.kpi.ua/2020_7-148. (in Ukrainian)

[5] M. Odinokaya, "Interactive learning technology usage in the students' individual work organization", Teaching Methodology in Higher Education, no.3(17), pp. 228 - 235, 2014. (in Russian)

[6] I. Zimnyaya, Psychology of teaching foreign languages at school. Moscow, Russian Federation: Prosveschenie, 1991. (in Russian)

[7] E. Malushko, "2.0 Approach to teaching foreign language listening in the russian masters' level", Bulletin of Volgograd State University, vol. 9, no. 11, pp. 175-180, 2013. (in Russian)

[8] V. Berbets, "Didactic principles and functions of using information and communication tools in future teachers' education", Collection of Scientific Papers of Uman State Pedagogical University, no.1, pp. 28-34, 2013. (in Ukrainian)

[9] M. Daver, "Motivation and strategic aspects of student-centered approach in learning Russian as a foreign language at the initial stage", Unpublished doctoral dissertation, Moscow, Russian Federation: The Pushkin State Russian Language Institute, 2008. (in Russian)

[10] I. Zadorozhna, "Model of organizing future English language teachers' autonomous learning on acquiring English language communicative competence", The Scientific Issues of Ternopil Volodymyr Hnatiuk National Pedagogical University. Series: pedagogy, no. 2, pp. 66-72, 2012. (in Ukrainian)

[11] E. Gardiner, Remote Teaching: When and How to Use Synchronous vs. Asynchronous Methods, 2021. [Online]. Available: https://tophat.com/blog/remote-teaching-when-and-how-to-use-synchronous-vsasynchronous-methods/. Accessed on: June 16, 2021. (in English)

[12] O. Vashchylo, Study Program for the Practical Course in English. Level: Vantage Profound 1. Specialty 035.041 "Germanic languages and literature (including translation), primary - English. Kyiv, Ukraine: Igor Sikorsky Kyiv Polytechnic Institute, 2020. (in Ukrainian)

[13] O. Vashchylo, "Methodology of teaching English monologue production to future mechanical engineers", Unpublished doctoral dissertation, Kyiv, Ukraine: Taras Shevchenko national University of Kyiv, 2020. (in Ukrainian)

[14] O. Vashchylo, Z. Kornieva, "Methodological fundamentals of teaching ESP monologue production to students majoring in mechanical engineering. Foreign languages, no. 1, pp. 10-18, 2020. (in Ukrainian)

[15] E. Sidorenko, Mathematical methods of data processing in psychology. St. Petersburg, Russian Federation: Rech, 2000. (in Russian)

[16] V. Chernov, Fundamentals of Fuzzy Sets Theory. Vladimir, Russian Federation: Vladimir State University, 2010. (in Russian)

[17] D. Hrihorieva, H. Hereeva, R. Basyrov, Fundamentals of Fuzzy Logic. Naberezhnye Chelny, Russian Federation: Kazan Federal University, 2018. (in Russian)

[18] D. Nazarov, L. Konysheva. Intellectual Systems: Fundamentals of Fuzzy Sets. Moscow, Russian Federation: Publishing house Yurait, 2018. (in Russian)

[19] [L. A. Zadeh. "Fuzzy sets". Information and control, vol. 8, no.3, pp. 338-353, 1965.

[20] V. Bosniuk, Mathematical methods in Psychology. Course of Lectures. Harkiv, Ukraine: National University of Civil Defence of Ukraine, 2016. (in Ukrainian)

[21] I. Bronshtein, K. Semendiaiev, Reference book on mathematics for engineers and students. Moskow, Russian Federation: Nauka, 1986. (in Russian)

Text of the article was accepted by Editorial Team on 17.07.2021

\title{
ОЦІНЮВАННЯ ЕФЕКТИВНОСТІ ДИСТАНЦІЙНОГО НАВЧАННЯ СТУДЕНТІВ-ФІЛОЛОГІВ В УМОВАХ ПАНДЕМІЇ COVID-19
}

\author{
Ващило Ольга Валеріївна \\ кандидат педагогічних наук, старша викладачка кафедри теорії, практики та перекладу англійської мови \\ Національний технічний університет України “Київський політехнічний інститут імені Ігоря Сікорського", \\ м. Київ, Україна \\ ORCID ID 0000-0001-7484-9435 \\ olga_VV@ukr.net
}


Анотація. Статтю присвячено опису організації дистанційного навчання майбутніх філологів англійської мови та оцінці ефективності запропонованого підходу. Дистанційне навчання проводилось на базі Національного технічного університету України «Київський політехнічний інститут імені Ігоря Сікорського» у третьому та четвертому семестрах 2020-2021 навчального року із залученням студентів другого курсу (дві навчальні групи) факультету лінгвістики спеціальності 035 «Філологія» спеціалізації 035.041 «Германські мови та літератури (переклад включно), перша - англійська». Освітній процес в дистанційному режимі передбачав проведення дистанційних навчальних занять з використанням сервісу відеоконференцій Zoom та самостійної роботи студентів з використанням навчальної платформи Canvas. Ефективність організації дистанційного навчання майбутніх філологів англійської мови перевірялась шляхом проведення зрізів знань на початку та по завершенню дистанційного навчання, 3 подальшою обробкою отриманих даних методами математичної статистики. Ефективність дистанційного навчання в цілому перевірялась із використанням статистичного критерію $\varphi^{*}$ Фішера. Мінімально достатній рівень навченості, який використовується для визначення критерію $\varphi^{*}$ Фішера, було розраховано 3 використанням теорії нечітких множин шляхом статистичної обробки думок групи експертів. Експертами виступили викладачі кафедри теорії, практики та перекладу англійської мови Національного технічного університету України «Київський політехнічний інститут імені Ігоря Сікорського» (загальною кількістю 10 респондентів). Ефективність дистанційного навчання в кожній навчальній групі перевірялась 3 використанням t-критерію Стьюдента для залежних вибірок. Результати статистичної обробки показали ефективність запропонованого підходу 3 організації дистанційного навчання майбутніх філологів англійської мови, який передбачав комплексне поєднання синхронного (з використанням програми відеоконференцій Zoom) та асинхронного режимів навчання (3 використанням навчальної платформи Canvas). Результати проведеного серед учасників навчального процесу опитування виявили їх позитивне ставлення до організації дистанційного навчання з використанням сервісу відеоконференцій Zoom та навчальної платформи Canvas.

Ключові слова: ефективність дистанційного навчання; статистичний критерій $\varphi^{*}$ Фішера; $\mathrm{t}$ критерій Стьюдента для залежних вибірок; сервіс відеоконференціїй Zoom; навчальна платформа Canvas.

\section{(cc) BY-NC-SA}

This work is licensed under Creative Commons Attribution-NonCommercial-ShareAlike 4.0 International License. 